\title{
GERMANY AND THE MONROE DOCTRINE
}

\author{
BY Dr. M. J. BonN, \\ Professor at the University of Munich, Bavaria.
}

The Monroe Doctrine can be approached from a purely theoretical point of view: the question can be asked whether it has any legal force; whether it is binding on other countries; whether it is right and justifiable that a sovereign country like the United States is acting as the guardian of other sovereign countries without.any request from them. German lawyers and political philosophers have been greatly interested in these questions. I have to acknowledge openly, that such is not the case with me. I look upon the Monroe Doctrine as a policy proclaimed and acted upon by, the United States in their own interest, and I am discussing that policy as a policy and not as a treaty. From that point of view the question I have to answer is very simple. Is Germany willing to respect the policy of the Monroe Doctrine? Or she is going to try and effect a permanent settlement in South America?

There are a great many people who believe in the existence of German plans of colonization in South America. Germany, they explain, is very densely populated. Her African colonies, even if she were to retain them after the war, cannot be settled by white people; but South America is a country where a superabundant white population from Germany might be settled.

Such ideas might have had some weight thirty years ago, when there was a big German emigration. Though the population of Germany has increased by nearly thirty millions, emigration has come to a standstill; there is even a yearly immigration of seasonal laborers of nearly three quarters of a million. For the purpose of settling a superabundant population, Germany does not want South America today, for she has no such population to settle. There will be no such emigration in the future, as long as German trade and German industries go on. If that trade was ever stopped permanently, even the excellent social organization of the German people could not prevent emigration. There is a movement abroad to bring about at the conclusion of the war a permanent commercial 102 
isolation of Germany; if that could be done, Germany would be in a very bad position. There would be permanent unrest in Europe and probably a very great emigration from Germany. It would scarcely settle in South America, but rather direct its course towards the United States. People in the United States, who are afraid of an increased German immigration, have a great interest in the continuation of German commercial activities after the war.

As far as the social and economic problems of Germany are concerned, they do not impel her towards an infringement of the Monroe Doctrine. They drove her to do business with South America, but that business was done on competitive lines, not based on monopoly, and she could go on doing that business peacefully, for the existence of the Monroe Doctrine prevented a scramble for South America, and maintained the principle of the open door.

It has often been said that in times passed the chief defense of the Monroe Doctrine has been the British Fleet. A permanent settlement in South America in opposition to England's wishes, would have been impossible to any nation. But England had really no reason to object to a permanent German settlement in South America. In fact, she would have liked it. It would not have taken anything away from her that she owned, nor that she was ever likely to get. It would have embroiled Germany with the United States and saddled her permanently with a problem, which would have kept her busy for many years. There were many hints in the British Press during the last fifteen years, that Germany might confer a benefit upon mankind, if she took up the control and the permanent reform of some South American country. England's goodwill could have easily been bought. It is different, of course, with the United States. Their friendship has been valued by the German government and the German people in times past; their desires have been respected. For after all that is the true meaning of the Venezuela incident as described so often lately. Germany declared explicitly that she did not want any permanent acquisition of Venezuelian soil. She considered it possible that during the blockade a temporary landing might be necessary. The United States, it seems, were afraid of a temporary landing being transformed into a permanent occupation. Whether the suspicion was justified or not, they resorted to what might be considered a threat. Germany gave in; she did not give in because she was afraid. Her 
policy is not carried out in such a haphazard way as to omit an ample measure of preparedness, if she had meant to effect a permanent occupation; she gave in because she valued the friendship of the United States higher than the possible advantage of bringing President Castro to terms quickly.

The chief protection for the Monroe Doctrine and its real permanent guarantee is the nature of the South American problem.

If South America was an uninhabited country, it might be easy to start a settlement, which in due time would develop into a daughter state. As British colonization has shown in Australia, no great strain on military or financial resources would follow. If South America was inhabited exclusively by lowly native races, occupation and conquest would be easy. Three thousand white Germans ruled thirteen million natives scattered over one million square miles in Africa. But South America is settled by people of Latin origin, there is no large German element amongst them. Of four and one-half million immigrants arriving in the Argentine Republic, two and one-quarter million were Italians; only sixty thousand were Germans. Of the total immigrants to Brazil 3.4 per cent were German. South America has been a Latin-Indian country in the past; it is becoming more Latin every day. Even if there were no native born South Americans, German immigrants could not come in great numbers as they could not compete with the standards of living of the Portuguese, Spaniards and Italians. Any South American country would have to be conquered against the will of her inhabitants, many of whom are of European stock. It would have to be taken by force of arms. It would have to be held in the same way. A large army would have to be quartered permanently to subdue the natives, and the security of this army would depend upon the unhampered control of the sea. Its safety, so to speak, would be at the mercy of any sea power. It would be a task ever increasing in size, for the natives of the newly acquired South American colony would be of the same origin as their free neighbors. These would back revolution and rebellion and bring about a permanent fight, which could only be settled by the conquest of the whole sub-continent, or by the ejectment of the would-be conquerors. England's experiences in South Africa have shown Germany the difficulty of such conquest. Though she had two 
friendly colonies, Cape Colony and Natal, which she could use as bases, England needed an army of three hundred thousand men to defeat a few thousand Boers. And England's experiences in Ireland have shown Germany the difficulties of holding subject a race of European stock. Ireland is only two and three quarters of an hour from England today; she has been colonized three times by English settlers; her inhabitants are few in number, and she has always been a source of weakness to her conqueror. To try to rule permanently many millions of alien races many thousand miles away, would be a task no sane German statesman would care to undertake. For Germany is a country surrounded by mighty nations; she has a national army organized for home defense; she cannot send them away as England did her professional soldiers to occupy permanently faroff continents.

The difficulty of achieving a permanent settlement in South America, which would benefit and not burden Germany, is the real reason why South America need not be afraid of Germany. And the existence of the Monroe Doctrine, which would prevent other nations from trying to play a game which Germany is too wise to indulge in, obviates any scramble for South America. Germany went into China because she was sure a partition of China was imminent. As long as the Monroe Doctrine continues, she need not be afraid of such a settlement in South America.

As time goes on the states of South America are getting stronger and sounder. Their governments will become more and more reliable, and the sources of friction of the past will diminish in number. And with them will disappear any incitement which in days gone by might have made a permanent acquisition of South American territory appear easy and profitable to people who did not take the trouble to face the real difficulties of occupation or colonization. 